in the formation of students' readiness for preventive activities are possible with the correspondence of structural components of readiness as a complex personal education of the future teacher and the content of pedagogical training in the university education system. The stage of realization of its purposes in practice of higher school is established (at the first stage primary representations about preventive activity, about functions and preventive actions of the teacher, essence of pedagogical support and prevention of negative habits in behavior of younger schoolboys are formed). At the third stage students master the technology of individual and creative preventive activities, the need to correlate the content of training future teachers for preventive work with the structural components of readiness as an important characteristic of pedagogical professionalism.

Key words: preventive pedagogical activity, readiness for preventive activity, structural components and criteria of its formation, stage-by-stage preparation for preventive activity.

Дата надходження статті: 29.04.2021 p. Рецензент: доктор педагогічних наук, доцент Чувасова Н.О .

\title{
МЕТОДИЧНИЙ СУПРОВІД САМООСВІТНЬОЇ ПІДГОТОВКИ ПЕДАГОГА ДО ФОРМУВАННЯ КЯЮЧОВИХ КОМПЕТЕНТНОСТЕЙ УЧНІВ У ЗАКЛАДАХ ЗАГАДЬНОЇ СЕРЕДНЬОЇ ОСВІТИ
}

Стаття присвячена визначенню й обьрунтуванню методичних рекомендацій щодо здійснення самоосвітньої підготовки вчителів до формування ключових компетентностей учнів у закладах загальної середньої освіти.

Представлені у статті результати проведеного дослідження щьоо готовності вчителів до формування ключових компететностей учнів, що полягали у пошуку труднощів у здійсненні иъіё діяльності та констатації даних щъодо сучасного стану цієё̈ готовності, зокрема, незначна кількість вчителів (26\%) готові формувати ключові компетентності учнів. Для вирішення проблеми обрано самоосвітню підготовку як ефективний спосіб підвищення професійної компетентності педагога.

Представлено розроблені методичні рекомендації, що сприяють якісному здійсненню самоосвітньої підготовки: виробити індивідуальний стиль; вивчати літературу; займатися самопізнанням; аналізувати освітній процес; здійснювати самоосвітню діяльність та ін.

Акцентовано, що впровадження розроблених методичних рекомендацій у самоосвітню практику педагогів ефективно здійснювати иляхом використання науково-методичного забезпечення, яке представлене сукупністю форм і методів (вправи для самопідготовки, тренінги, творчі індивідуальні і групові завдання, практикуми, семінари та ін.), що сприяють підвищенню рівня фахової підготовки вчителя.

Визначено найбільи продуктивні форми самоосвітньої підготовки, професійний саморозвиток серед індивідуальних, мережеві педагогічні спільноти серед групових. Зроблено висновок про те, щзо визначені рекомендації $i$ форми самоосвітньої підготовки сприяють активізації когнітивної, емоційної $і$ змістової діяльності педагогів, а також є основною рушійною силою особистісного і професійного розвитку, що проявляеться у формуванні власного стилю професійної діяльності, самовдосконаленні та становленні професіонала.

Ключові слова: самоосвітня підготовка педагога, ключові компетентності учнів, заклади загальної середнвої освіти, компетентнісний підхід, освітній проиес, готовність вчителя, самоосвіта вчителя.

*С Левченко Ф.Г.

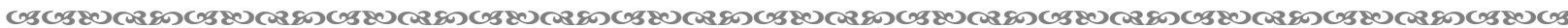
153 
Постановка проблеми. Зміни, що відбуваються в сучасному освітньому процесі впродовж останнього десятиріччя, сприяли оновленню змісту освіти, забезпеченню безперервного процесу становлення та розвитку гармонійної творчої особистості учня. У свою чергу перед вчителем постає завдання переосмислення того, як змінюється наше життя, наука, школа, вчительська праця, особистість учня.

Учасники освітнього процесу сьогодні мають бути не лише носіями знань, а й розвиватися як творчі особистості, які здатні використовувати здобуті знання для конкурентоспроможної діяльності у будь-якій сфері суспільного життя,тобто сформуватися компетентними особистостями. Саме в такому спрямуванні освітньої діяльності постає питання про їі організацію з точки зору компетентнісного підходу, а отже, й окреслена проблема є надзвичайно актуальною і своєчасною.

Головним персонажем, який реалізує даний підхід в освіті, є вчитель, діяльність пов'язується з творчою самостійністю, пошуком, високим професіоналізмом. Інакше висловлюючись: активна професійна позиція повинна стати способом життя кожного вчителя.

Аналіз досліджень. Проблемі вдосконалення системи освіти шляхом упровадження компетентнісного підходу присвячені праці Дж. Равена, А. Андреєва, І. Зимньої, О. Овчарук, Р. Пастушенка, О. Пометун, Г. Селевка, А. Хуторського та ін. Досвід упровадження компетентнісного підходу в освіті проаналізований у працях Н. Бібік, Л. Ващенка, І. Ермакова, І. Зимньої, О. Локшиної, О. Овчарук, Л. Паращенко, О. Пометун, О. Савченко, С. Трубачевої, А. Хуторського та ін.

Наукові розвідки В. Вершиніна, А. Громцевої, М. Гузика, С. Аисенкової, В. Онищук, І. Підласого, В. Шаталова висвітлюють ідею самоосвітньої спрямованості процесу навчання. Питання активізації пізнавальної та самоосвітньої діяльності розгдядають у своїх працях психологи Д. Богоявленський, Н. Менчинська, Т. Щукіна, дидакти М. Данилов, І. Дернер, М. Скаткін та інші.

Предметом наукового пошуку Н. Бухлової $е$ самоосвітня діяльність. Однак проблемам самоосвітньої підготовки вчителя приділено недостатньо уваги, зокрема питанню готовності вчителя до формування компетентностей учнів.

Учені-педагоги і психологи (Д. Алфьорова, М. Ермоленко, Н. Кузьміна, А. Маркова, В. Мижерикова, Н. Разіна, С. Романова, А. Хуторський, Є. Царькова, С. Чеботарьова, С. Шишова та ін.) займалися проблемою професійної компетенції і компетентності вчителя. У вітчизняних науково-педагогічних досдідженнях цю проблему аналізували А. Богуш, С. Бондар, Н. Глинянюк, Є. Павлютенков, С. Тищенко та ін.

На підставі аналізу психолого-педагогічної літератури 3 окресленої проблеми з'ясовано, що, незважаючи на висвітлення питань самоосвітньої діяльності взагалі, а також професійної компетентності і самоосвітньої компетентності, необхідним є вивчення самоосвітньої підготовки вчителя щодо формування кдючових компетентностей учнів, зокрема - методичного супроводу, що реалізується у відповідних методичних рекомендаціях з метою ефективного здійснення цього виду діяльності.

Мета статті - обгрунтувати методичні прийоми самоосвітньої підготовки вчителя до формування ключових компетентностей учнів у закладах загальної середньої освіти.

Виклад основного матеріалу. Інноваційні процеси в освіті вимагають оновлення освітнього середовища, змісту освіти, інноваційних форм і методів навчання. Зростаючі вимоги до якості знань, ускладнення форм організації уроку - все це вимагає підвищення професійної компетентності та мотивування вчителя до самоосвітньої діяльності з метою реалізації ідей компетентнісно орієнтованого навчання.

У Середньостроковому плані пріоритетних дій Уряду до 2020 року наголошується на необхідності модернізації підготовки педагогічних кадрів та системи підвищення їх кваліфікації для забезпечення вимог суспільства до якості надання освітніх послуг,

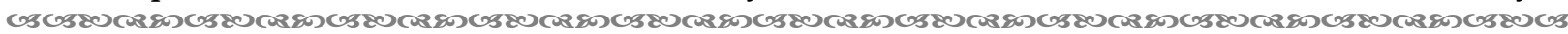
154 
розвитку в молоді активної громадянської позиції [6].

Адже педагогічна діяльність, будучи сплавом науки й мистецтва, завжди припускає творчість, практично втілювану в нестандартний підхід до рішення проблем; розробка нових методів, форм, прийомів і засобів та їх оригінальних сполучень; ефективне застосування наявного досвіду; удосконалення раціоналізації модернізації відомого відповідно до нових задач; удала імпровізація на основі як точного знання й компетентного розрахунку, так і високорозвиненої інтуїції; уміння бачити «віяло варіантів» рішення однієї й тієї ж проблеми; уміння трансформувати методичні рекомендації, теоретичні напрацювання в конкретних педагогічних діях тощо [5].

Вивчення результатів психолого-педагогічних і соціологічних досліджень, аналіз реальної шкільної практики, аналіз педагогічної діяльності вчителів, анкетування й опитування дади можливість визначити такі проблеми і труднощі у практиці роботи вчителів щодо формування кдючових компетентностей учнів закладів загальної середньої освіти, зокрема:

- зниження рівня професійної діяльності вчителів, їх методичної майстерності, що підтверджується при проведенні навчальних занять, у процесі атестації;

- зниження творчого рівня методичної роботи і відсутність у ній елементів експериментальної діяльності;

- низький рівень педагогічної майстерності вчителя для реалізації компетентнісно орієнтованого навчання;

- відсутність комплексу науково-методичного забезпечення, що відповідае вимогам навчальних стандартів, сприяе формуванню компетентності учнів.

Резудьтатами науково-педагогічного пошуку встановлено, що усвідомденням недостатності досягнутих результатів і бажанням їх поліпшити керуються в своїй педагогічній діядьності - 20 \% педагогів; високим рівнем професійних досягнень, сильною потребою в досягненні високих резудьтатів - $20 \%$; потребою в контактах 3 цікавими, творчими людьми - 53,3 \%; бажанням створити нову, ефективну школу для дітей - $20 \%$; потребою в новизні, оновленні, зміні обстановки, подоланні рутини 26,6 \%; потребою в лідерстві - 6,6\%; потребою в пошуку, дослідженні, кращому розумінні закономірностей - $20 \%$; потреба в самовираженні, самовдосконаленні - $20 \%$; відчуттям власної готовності брати участь в інноваційних процесах, упевненістю в собі $20 \%$; бажанням перевірити на практиці отримані знання при нововведеннях - 6,6 \%; потребою в ризику - 0 \%; матеріальними причинами: підвищенням заробітної плати, можливістю пройти атестацію і т.д. - 46,6\%; прагненням бути поміченим і гідно оціненим - $40 \%$.

Проведене дослідження дозволило виявити у педагогів наступні труднощі: слабка інформованість в колективі про можливі інновації - у 6,6 \% педагогів; переконання, що ефективно навчати можна і по-старому - у 20 \%; погане здоров'я, інші особисті причини - у 33,3 \%; велика навчальне навантаження - у $40 \%$; невеликий досвід роботи - у $20 \%$; відсутність матеріальних стимулів - у $40 \%$; почуття страху перед негативними результатами - у $20 \%$; розбіжності, конфлікти в колективі - у 6,6\%.

Результати дослідження показали, що більшість педагогів сприймають нововведення помірно - 40 \%, тобто не прагнуть бути серед перших, але й не хочуть бути серед останніх. Тоді як 26,6\% педагогів відносять себе до тих, що вододіють високим рівнем новаторства, зокрема готові реалізовувати компетентнісний підхід у навчанні.

Представлені результати пошуку щодо стану готовності вчителів до реалізації ідей компетентнісного підходу у закладах загадьної середньої освіти дають підстави для пошуку шляхів вирішення проблеми, що склалася.

Найбільш ефективним способом підвищення педагогічної компетентності вважається самоосвіта вчителя.

Самоосвіта е усвідомленою потребою в постійному вдосконаленні власної професійної діяльності з акцентом на їі соціалізацію, на створення умов для розвитку

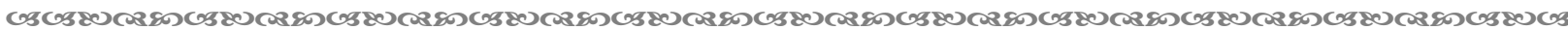
155 
особистісно і соціально значущих якостей особистості вихователя та особистості кожної дитини.

Закон України «Про освіту» визначає самоосвіту як інформальну освіту, яка передбачає самоорганізоване здобуття особою певних компетентностей, зокрема під час повсякденної діяльності, пов'язаної з професійною, громадською або іншою діядьністю [3].

Систему самоосвіти вчителя можна розглядати як сукупність складових: самооцінка - вміння оцінювати свої мождивості; самооблік - вміння брати до уваги наявність своїх якостей; самовизначення - вміння вибирати своє місце в житті, в суспільстві, усвідомити свої інтереси; самоорганізація - вміння знайти джерело пізнання й адекватні своїм можливостям форми самоосвіти, планувати, організовувати робоче місце та діяльність; самореалізація - реалізація особистістю своїх мождивостей; самокритичність - вміння критично оцінювати переваги та недоліки власної роботи; самоконтроль - здатність контродювати свою діяльність; саморозвиток - результат самоосвіти [2].

Самоосвітня діяльність вчителя не має звужуватися до процесу елементарного відновлення знань, якими овододіє останній. Це перш за все процес ознайомлення 3 новітніми дослідженнями у галузі педагогіки та психології, пошук нових напрямків уметодиці та організації освітнього процесу, розгляд педагогічних проблем, що викдикають утруднення в практичній роботі на високому науковому рівні.

Задля ефективного здійснення самоосвітньої підготовки було розроблено методичні рекомендації для вчителів, а саме:

1) виробити й усвідомити індивідуадьний стиль своєї педагогічної діядьності, педагогічного спілкування;

2) вивчати літературу з проблеми психолого-педагогічної компетентності;

3) активно займатися самопізнанням особистісних і професійних особливостей 3 метою використання своїх можливостей в освітньому процесі;

4) регулярно аналізувати освітній процес, що дозволить своєчасно виявити професійні труднощі і помилки;

5) підвищувати свій рівень психодого-педагогічної компетентності як особистісну і професійну ціннісну орієнтацію;

6) здійснювати самоосвітню діяльність, враховуючи сучасні тенденції у системі освіти, зокрема - реалізацію компетентнісно орієнтованого навчання;

7) регулярно аналізувати свій життєвий і професійний досвід 3 метою овододіння адекватною особистісною та професійною самооцінкою;

8) усвідомити, що вміння вирішувати конфліктні ситуації на практиці є життевонеобхідним і відпрацьовувати у себе практичні навички вирішення конфліктних ситуацій.

Представлена система методичних рекомендацій впроваджувалася у процесі роботи із педагогами, які брали участь у опитуванні, щоб їхня самоосвітня діяльність здійснювалася відповідно до існуючих нововведень в освітньому процесі закладів загадьньої середньої освіти i носила системний характер. Упровадження запропонованих методичних рекомендацій у представленій сукупності відбувалося шляхом використання відповідно розробленого науково-методичного забезпечення.

Науково-методичне забезпеченням підготовки вчителя до реалізації ідей компетентнісно орієнтованої освіти у закладах загадьної середньої освіти представдяє сукупність форм і методів, що сприяють підвищенню рівня фахової підготовки вчителя. Зокрема, це створення умов для формування творчої особистості педагога і підтримки професійної форми його діяльності. Дотримання цих умов сприяе розвитку в учителя педагогічної системи, в якій він проявляе себе у ролі помічника дослідницької діяльності учнів, а також виробленню педагогічної техніки для спонукання до творчої 
діяльності учнів, спрямованої на посдідовне досягнення іiі творчої продуктивності та формування в учня відповідних компетентностей.

Найбільш поширеними формами роботи з учителями, на нашу думку, є вправи для самопідготовки, тренінги, творчі індивідуальні та групові завдання, практикуми, семінари та ін. Виявденню ефективних форм роботи 3 учителями в умовах компетентнісно орієнтованої освіти сприяло проведення дослідження, результати якого показали, що професійний саморозвиток є найбільш продуктивною індивідуальною формою самоосвітньої підготовки, а мережеві педагогічні спільноти - груповою.

Розглядаючи професійний саморозвиток як ефективну індивідуальну форму самоосвітньої підготовки, зазначимо, що професійні саморозвиток і самовиховання це свідома діяльність, спрямована на вдосконалення своеї особистості відповідно до професійних вимог [7].

Сутність професійного саморозвитку педагога базується на двох підходах. Перший пов'язаний із саморозвитком самої особистості педагога, другий - зі статусом цього педагога в тій чи іншій системі професійної діяльності. Загальним для того й іншого підходу є, те що індивідуальні здібності певної людини і соціальне середовище, в якому вона перебуває, взаємопов'язані, що процес саморозвитку має свої етапи, що особистісний розвиток залежить від професійного.

Основними компонентами професійного саморозвитку вважаються: самопізнання себе 3 професійної точки зору, постійне самовизначення, розвиток професійних навичок, самопроєктування, створення певної стратегії для зростання 3 професійної точки зору своєї діяльності, самоорганізація і самоврядування [2].

Найпоширенішими формами роботи 3 професійного саморозвитку педагога є: робота над єдиною методичною темою, над темою тимчасових творчих груп, використання програмно-цільового і проєктного підходів, семінари на постійній основі, педагогічні ради.

Ефективному саморозвитку сприяють вправи: «Чарівний глечик», «Оплески», «Крок до успіху», «Поле вражень». Зазначені вправи здебільшого вкдючають до програм тренінгів з професійного зростання, бо їх використання сприяє виявленню сильних і слабких сторін професійного саморозвитку вчителя, формуванню професійних якостей, перевірці стану впровадження у практику роботи вчителя нових прийомів, форм, методів, методик роботи із учнями. Сприятливим буде вкдючення даних вправ у роботу семінарів, педагогічних рад, методичних тижнів (фестивалів) тощо для активізації самоосвітньої роботи педагога.

Мережеві педагогічні спільноти є віртуальними об'єднаннями за професійною ознакою, контент спілкування яких пов'язаний із фаховими питаннями або спільною продуктивною професійною діяльністю в мережі [4].

Метою таких об'єднань є обговорення професійних проблем, інформаційнометодична підтримка, створення бази навчально-методичних ресурсів, поширення перспективного педагогічного досвіду тощо. Об'єднання діє за умови наявності організаційної структури, яка забезпечує мождивість спілкування в мережі, та мотивації діяльності.

Найбільш поширеними формами роботи, які використовує спільнота, є: навчальні семінари; віртуальні конференції; конкурси, акції; «майстерні» або майстер-класи; опитування, обговорення в чаті; фестиваль проєктів; створення сайтів, тощо. Це дає можливості кожному учаснику спільноти обрати власну траєкторію професійного зростання. Для самоосвітньої діяльності педагога дуже важдиве спілкування з колегами. Завдячуючи мережевому співтовариству, вчитель може у зручний час, маючи доступ до Інтернету, спілкуватися зі своїми колегами й однодумцями, що сприяе підвищенню рівня професійної культури, а також спонукає до саморозвитку і самовдосконалення.

Висновки. Здійснене дослідження дає підстави для висновків про те, що саморозвиток педагога є основною рушійною силою особистісного і професійного

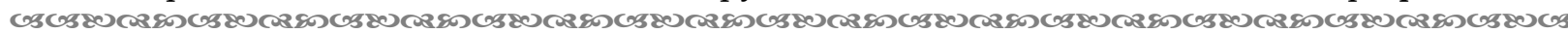


розвитку, сприяє формуванню власного стилю в професійній діяльності, який базується на загальноприйнятих дидактичних засадах і відповідає сучасним тенденціям у сфері освіти, що допомагає осмислити свою сутність у професії, сприяе самовдосконаленню і становленню професіонала, а також ефективності розвитку мережевих педагогічних спільнот.

Визначені у дослідженні методичні рекомендації щодо ефективного здійснення самоосвітньої діяльності педагогів спрямовують до формування кдючових компетентностей учнів у закладах загальної середньої освіти, сприяють активізації основних складових професійного саморозвитку, а саме: когнітивної - пізнання себе, міжособистісного спілкування, стереотипних уявлень, стильових особливостей; змістової - особливостей розвитку педагога в умовах компетентнісно орієнтованого навчання, визначенню основної суті для кожного учасника, змісту професійної діяльності, ставленню до себе як до особистості, як до професіонала, ставленню до праці та до професії, визначенню професійних перспектив тощо; мотиваційної, що полягає в актуалізації мотивів під впливом різноманітних умов (ситуацій) професійної діяльності (розв'язання проблем, прийняття рішень).

Представлене науково-методичне забезпечення, що вкдючає ефективні форми і методи роботи 3 педагогами сприяє: організації спільної діяльності; створенню єдиного інформаційного простору; обміну досвідом, підтримкою і співробітництвом; поширенню успішних педагогічних практик; організації формального і неформального спілкування на професійні теми; ініціації віртуальної взаємодії для подальшої взаємодії поза Інтернетом; підтримці нових освітніх ініціатив, зберіганню інформації у вигляді текстів, аудіо та відеоматеріалів, які містять навчально-виховний зміст; розміщенню своїх файлів і користуванню доступними в бібліотеці спільноти; спілкуванню (форум, чат, коментарі); участі в конкурсах, акціях, проєктах, обговореннях; створенню власних електронних сторінок (портфоліо).

Подальшого наукового розгляду потребує обгрунтування методичної системи самоосвітньої підготовки вчителя до формування кдючових компетентностей учнів у закладах загальної середньої освіти.

\section{Список використаних джерел:}

1. Бухлова Н. Організація самоосвітньої діяльності учнів. Харків: Основа, 2003. 67 с.

2. Жорова I., Кузьмич Т., Назаренко Л. Самоосвіта педагога як умова підвищення його професійної компетентності: методичні рекомендації. Херсон: РІПО, 2012. 80 с.

3. Закон України «Про освіту». URL: https://zakon.rada.gov.ua/laws/show/2145-19

4. Осадчий В. Мережеві педагогічні співтовариства як засіб удосконалення професійної підготовки вчителів. Інформаційні технологї̈ і засоби навчання. 2010. № 4 (18). С. 60-67.

5. Поташник М., Левит М. Освоение ФГОС: методические материалы для учителя. Москва: Педагогическое общество России, 2016. 185 с.

6. Про затвердження середньострокового плану пріоритетних дій Уряду до 2020 року та плану пріоритетних дій Уряду на 2017 рік: розпорядження КМ від 3 квітня 2017 р. № 275-p. URL: https://zakon.rada.gov.ua/laws/show/275-2017-\%D1\%80\#Text

7. Смолюк А. Теоретичний аналіз проблеми професійного саморозвитку майбутніх учителів початкової школи. Педагогічний часопис Волині. 2016. № 2 (3). С. 40-47.

\section{References:}

1. Bukhlova, N. (2003). Orhanizatsiia samoosvitnoi diialnosti uchniv [Organization of students' selfeducational activities]. Kharkiv: Osnova [in Ukrainian].

2. Zhorova, I., Kuzmych, T., \& Nazarenko, L. (2012). Samoosvita pedahoha yak umova pidvyshchennia yoho profesiinoi kompetentnosti: metodychni rekomendatsii [Teacher's self-education as a condition for increasing his professional competence: methodical recommendations]. Kherson [in Ukrainian].

3. Law of Ukraine "On Education". Retrieved from https://zakon.rada.gov.ua/laws/show/2145-19 [in Ukrainian]. 
4. Osadchyi, V. (2010). Merezhevi pedahohichni spivtovarystva yak zasib udoskonalennia profesiinoi pidhotovky vchyteliv [Online pedagogical communities as a means of improving teacher training]. Informatsiini tekhnolohii i zasoby navchannia, (18), 60-67 [in Ukrainian].

5. Potashnik, M., \& Levit, M. (2016). Osvoenie FGOS: metodicheskie materialy dlia uchitelia [Mastering the Federal State Educational Standard: teaching materials for teachers]. Moskva: Pedagogicheskoe obshchestvo Rossii [in Russian].

6. On approval of the medium-term plan of priority actions of the Government until 2020 and the plan of priority actions of the Government for 2017: Order of the Cabinet of Ministers dated April 3, 2017 No. 275-r. Retrieved from https://zakon.rada.gov.ua/laws/show/275-2017$\%$ D1\%80\#Text [in Ukrainian].

7. Smoliuk, A. (2016). Teoretychnyi analiz problemy profesiinoho samorozvytku maibutnikh uchyteliv pochatkovoi shkoly [Theoretical analysis of the problem of professional self-development of future primary school teachers]. Pedahohichnyi chasopys Volyni, 2(3), 40-47 [in Ukrainian].

Levchenko F. G., orcid.org/0000-0003-4295-2934

\section{METHODICAL SUPPORT OF SELF-EDUCATIONAL TRAINING OF THE TEACHER FOR FORMATION OF STUDENTS' KEY COMPETENCIES IN THE INSTITUTIONS OF GENERAL SECONDARY EDUCATION}

The article is devoted to the definition and substantiation of methodological recommendations for the implementation of self-education of teachers for the formation of students' key competencies in the institutions of general secondary education.

The article presents the results of a study on the readiness of teachers to form students' key competencies, which consisted in finding difficulties in carrying out this activity and finding data on the current state of this readiness, in particular, a small number of teachers $(26 \%)$ are ready to form key competencies. To solve the problem, self-educational training was chosen as an effective way to increase the professional competence of the teacher.

Such developed methodical recommendations promoting qualitative realization of self-educational preparation as to develop individual style; to study literature; to engage in self-knowledge; to analyze the educational process; to carry out self-educational activities, etc are presented.

It is emphasized that the implementation of the developed methodological recommendations in the self-educational practice of teachers can be effectively carried out by using scientific and methodological support, which is represented by a set of forms and methods (exercises for self-preparation, trainings, creative individual and group tasks, workshops, seminars, etc.), which help to increase the level of professional training of teachers.

The most productive forms of self-educational training, professional self-development among individual, network pedagogical communities among group ones are defined. It is concluded that certain recommendations and forms of self-education contribute to the activation of cognitive, emotional and semantic activities of teachers, and they are the main driving force of personal and professional development, manifested in the formation of their own style of professional activity, self-improvement and professional development.

Key words: self-educational teacher training, key competencies of students, the institutions of general secondary education, competence approach, educational process, teacher's readiness, teacher's self-education.

Дата надходження статті: 27.04.2021 p. Рецензент: доктор педагогічних наук, професор Тименко В. П. 